\title{
Comparison of Spent Fuel Management Fee Collection Alternatives
}

\author{
M. K. White \\ R. L. Engel
}

January 1979

Prepared for the U.S. Department of Energy under Contract EY-76-C-06-1830

Pacific Northwest Laboratory Operated for the U.S. Department of Energy by Battelle Memorial Institute 


\title{
NOTICE
}

This report was prepared as an account of work sponsored by the United States Government. Neither the United States nor the Department of Energy, nor any of their empioyees, nor any of their contractors, subcontractors, or their employees, makes any warranty, express or implied, or assumes any legal liability or responsibility for the accuracy, completeness or usefulness of any information, apparatus, product or process disclosed, or represents that its use would not infringe privateiy owned rights.

The views, opinions and conclusions contained in this report are those of the contractor and do not necessarily represent those of the United States Government or the United States Department of Energy.

\author{
PACIFIC NORTHWEST LABORATORY \\ operated by \\ BATTELLE \\ for the \\ UNITED STATES DEPARTMENT OF ENERGY \\ Under Contract EY-76-C-06-1830
}
Printed in the United States of America
Avallable from
National Technical Information Service United States Department of Commerce
5285 Port Royal Road
Springfield, Virginia 22151

Price: Printed Copy $\$$

; Microfiche $\$ 3.00$

NTIS

-Pages Selling Price

$\begin{array}{lr}001-025 & \$ 4.00 \\ 026-050 & \$ 4.50 \\ 051-075 & \$ 5.25 \\ 076-100 & \$ 6.00 \\ 101-125 & \$ 6.50 \\ 125-150 & \$ 7.25 \\ 151-175 & \$ 8.00 \\ 176-200 & \$ 9.00 \\ 201-225 & \$ 9.25 \\ 226-250 & 59.50 \\ 251-275 & \$ 10.75 \\ 276-300 & \$ 11.00\end{array}$




\section{3679000493942}

COMPARISON OF SPENT FUEL

MANAGEMENT FEE COLLECTION

ALTERNATIVES

M. K. White

R. L. Engel

January 1979

Prepared for the U.S. Department of Energy under Contract EY-76-C-06-1830

Pacific Northwest Laboratory

Richland, Washington 99352 


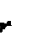

$\therefore$ 


\section{CONTENTS}

1.0 INTRODUCTION ...................................... 1

2.0 PERSPECTIVES ON THE CRITERIA .................... 2

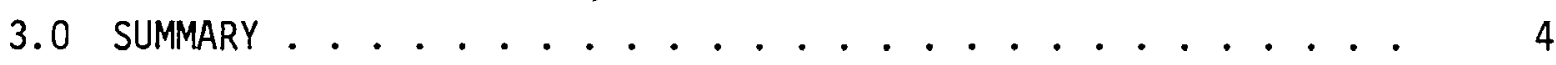

4.0 CRITERIA EVALUATIONS $\ldots \ldots \ldots$

5.0 CRITERIA EVALUATIONS WITH MODIFIED STORAGE AND DISPOSAL REQUIREMENT ..................... 18

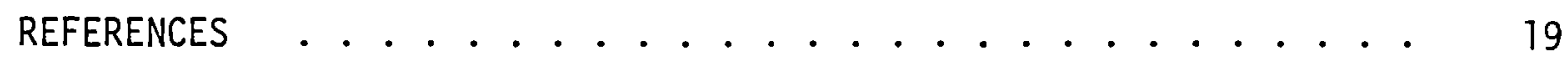

APPENDIX A - BASIC FEE METHODOLOGY AND DATA FOR CRITERIA 1

AND 2 EVALUATIONS ................ A-1

APPENDIX B - DATA FOR CRITERION 3 EVALUATION . . . . . . B B-1

APPENDIX C - DATA FOR CRITERION 4 EVALUATIONS . . . . . . . C C

APPENDIX D - DATA FOR REVISED STORAGE AND DISPOSAL DEMAND CALCULATIONS ................... D-1 


\subsection{INTRODUCTION}

In October of 1977 the Department of Energy (DOE) announced a new spent nuclear fuel policy. As part of that policy the government proposed to take title to and store nuclear fuel from private power reactors for a one-time fee. In July of 1978 DOE issued a report entitled "Preliminary Estimates of the Charge for Spent Fuel Storage and Disposal Services (DOE/ET-0055)"1 which gave a preliminary description of the methodology for calculating a fee and the resulting fee for a variety of assumptions.

The interagency Nuclear Waste Management Task Force was established by President Carter in March of 1978 to formulate recommendations for Administration policy for long-term management of nuclear wastes. As part of their review of government programs and policies relating to waste management this group reviewed the spent nuclear fuel policy. In the "Report to the President by the Interagency Review Group on Nuclear Waste Management (TID-28817 $($ draft $))^{\prime 2}$, the Interagency Review Group (IRG) endorsed the principle of full recovery of government costs of managing spent nuclear fuel from the users of those services. The IRG recommended that DOE investigate the alternative methods of recovering these costs "to determine the method of payment which will best serve the combined interest of the public and the ratepayer."

This report is in response to that recommendation. Several fee collection mechanisms ranging from payment at power generation to payment at fuel delivery have been evaluated to determine how well they satisfy four specific criteria. The results are intended to provide data for the government decision-making process. As part of that process, the relative importance of various criteria for evaluating candidate collection mechanisms must be determined. The data from this report, considered in the perspective of the relative importance of the criteria should provide a basis for choosing the most favorable fee collection scheme. 
. 


\subsection{PERSPECTIVES ON THE CRITERIA}

The following observations are offered prior to the detailed results of the analyses to assist the reader in placing the evaluations of the criteria in proper perspective.

\section{CRITERION 1 GOVERNMENT OUTLAYS SHOULD BE MINIMIZED}

The alternative payment mechanisms create a wide range of cash flow situations. Early collection mechanisms (power generation, fuel discharge) place the government in an interim position of managing large trust funds (\$.5-2 Billion). Later collection mechanisms cause large government outlays ( $-\$ 1$ to $-\$ 3$ Billion) that are recovered later in the period. Because of differences in the cost of capital for utilities and the federal government, large negative government cash flows are advantageous to nuclear power customers at the expense of the general taxpayer. Large positive government cash flows benefit the general taxpayer at the expense of the nuclear power customer. The combined interests of the public and the ratepayer are best served when neither large negative nor large positive cash flows occur.

CRITERION 2 - THE ECONOMIC IMPACT OF THE FEE COLLECTION MECHANISM ON THE ELECTRICITY USER SHOULD BE MINIMIZED

The impact of fee payment mechanisms on the cost of electricity to the customer ranges from $.20 \mathrm{mi} 11 \mathrm{~s} / \mathrm{kWh}$ to $.27 \mathrm{mills} / \mathrm{kWh}$. Although this difference represents approximately $\$ 430,000 /$ year to a utility operating a 1000 MWe nuclear power plant, from the perspective of an individual customer, the electricity rate would be impacted less than .5\%. Consequently, this criterion may be of lower significance in the selection of a fee collection mechanism.

CRITERION 3 - ALL GOVERNMENT COSTS FOR SPENT FUEL MANAGEMENT SHOULD BE FULLY RECOVERED FROM THOSE USING POWER GENERATED BY THE SPENT. FUEL

Because of uncertainties inherent in establishing a fee, no fee collection mechanism can guarantee that the appropriate individual customer pays the entire costs for managing his spent fuel. Early fee collection 
mechanisms tend to increase the probability that the individual electricity customer wi1l pay an appropriate rate for the utility to accumulate the fee which will be in effect when the utility-government fee transaction takes place. However, in times of cost increases, the fee in effect at the time of the government-utility transaction tends to be underestimated. Later payment mechanisms increase the likelihood that the utility will pay the appropriate fee in its transaction with the government, but makes it more difficult for the utility to collect its entire cost from the appropriate individual ratepayer. Thus, there is a natural tradeoff between early and late payment mechanisms that must be considered in evaluating this criterion.

CRITERION 4 - THE FEE COLLECTION MECHANISM SHOULD NOT DISCOURAGE UTILITIES FROM PROVIDING THEIR OWN SPENT FUEL STORAGE

From the standpoint of cost savings, all payment mechanisms tend to encourage the individual utility to expand existing reactor storage facilities to avoid using Federal AFR Storage facilities. Later fee collection mechanisms (those tied to fuel delivery) tend to encourage at-reactor storage expansion even after the repository is available for direct disposal. Early payment mechanisms (those tied closely to power generation) encourage the utilization of repository services once they are available. 


\subsection{SUMMARY}

Five alternative methods for recovering the costs of spent fuel management were evaluated. These alternatives consist of collecting the fee for various components of spent fuel management cost (AFR basin storage, transportation from AFR basin to the repository, packaging, repository, R\&D, and government overhead) at times ranging from generation of power to delivery of the spent fuel to the government. Table 1 shows the five alternative fee collection schemes and the calculated fee values. The Storage Fee (AFR basin storage and transportation from the AFR basin to the repository) was assumed collected either at the time of delivery of fuel to the AFR basin, or five years previous to delivery. Collection of a Disposal Fee for the remaining components was assumed feasible at any time from power generation to spent fuel delivery to the government.

TABLE 1. Alternative Spent Fuel Fee Collection Schemes

\begin{tabular}{ll} 
& \multicolumn{2}{c}{ Iime of Collection } \\
Power Generation Five Years Before & Fuel Discharge Fuel Delivery Delivery
\end{tabular}

Fee 1

Storage Fee

Disposal Fee

Fee 2

Storage Fee

Disposal Fee

Fee 3

Storage Fee

Disposal Fee

Fee 4

Storage Fee

Disposal Fee

Fee 5

Storage Fee

Disposal Fee

(R\&D and Overhead)

Disposal Fee

(Packaging and Repository)
$597 / \mathrm{kg}$

$.265 \mathrm{mills} / \mathrm{kwh}$

$\$ 97 / \mathrm{kg}$

$\$ 73 / \mathrm{kg}$

$\$ 97 / \mathrm{kg}$

$\$ 86 / \mathrm{kg}(\$ 73 / \mathrm{kg})$ *

*Storage customers pay a discounted disposal fee due to early paymen:

$\$ 130 / \mathrm{kg}$

$5118 / \mathrm{kg}(598 / \mathrm{kg})$ *

$\$ 130 / \mathrm{kg}$

$.074 \mathrm{mills} / \mathrm{kWh}$

$\$ 86 / \mathrm{kg}(\$ 66 / \mathrm{kg}) \star$ 
This list of candidates was chosen to illustrate the potential tradeoffs between early and deferred collection of the fees. Other fee collection mechanisms are possible, but they are likely to be similar enough to one or more of the alternatives assessed that their advantages or disadvantages may be inferred from the results of these analyses.

The five fee collection mechanisms were analyzed to determine how well they satisfy four criteria which relate to serving the interests of the public and the electricity ratepayer:

1. Government outlays should be minimized.

2. The economic impact of the fee collection mechanism on the electricity user should be minimized.

3. All government costs for spent fuel management should be fully recovered from those using power generated by the spent fuel.

4. The fee collection mechanism should not discourage utilities from providing their own spent fuel storage.

The abilities of the fee collection mechanisms to satisfy these criteria are summarized below on Table 2. The results shown are discussed further in the detailed results for each fee scheme in Section 4.0. The methodology for the calculations is discussed in the Appendices.

\section{TABLE 2. Summary of Criteria Evaluations}

\begin{tabular}{|c|c|c|c|c|c|c|}
\hline & \multirow{2}{*}{$\begin{array}{l}\text { Criterion } 1 \\
\text { Maximum } \\
\text { Future Value } \\
\text { of Government } \\
\text { Cash Flow } \\
\text { (\$ Millions) }\end{array}$} & \multirow{2}{*}{$\begin{array}{c}\text { Criterion } 2 \\
\\
\text { Economic } \\
\text { Impact on } \\
\text { Electricity Price } \\
\text { (mills/kwh) } \\
\end{array}$} & \multicolumn{2}{|c|}{ Criterion 3} & \multicolumn{2}{|c|}{ Criterion 4} \\
\hline & & & $\begin{array}{l}\text { Range of } \\
\text { variation of } \\
\text { Fee with } \\
\text { cost Changes } \\
\text { (percent) } \\
\end{array}$ & $\begin{array}{l}\text { Percentage of } \\
\text { Fee Recovered from } \\
\text { Electricity User } \\
\text { (percent) } \\
\end{array}$ & $\begin{array}{l}\text { Incentive to } \\
\text { Build Storage } \\
\text { in } 1987 \\
\text { (5 Millions) } \\
\end{array}$ & $\begin{array}{l}\text { Incentive to } \\
\text { Build Storage } \\
\text { in } 1988 \\
\text { (s Millions) }\end{array}$ \\
\hline Fee 1 & 1433 & .265 & -16 to 65 & 100 & 3.9 & 0 \\
\hline Fee 2 & 862 & .252 & -17 to 27 & $9 i$ & 3.9 & 0 \\
\hline Fee 3 & -1090 & .231 & -16 to 14 & 86 & 5.8 & 2.4 \\
\hline Fee 4 & -2405 & .197 & -10 to 1 & 83 & 4.9 & 2.0 \\
\hline Fee 5 & -1435 & .216 & -13 to 1 & 30 to 100 & 4.3 & 1.5 \\
\hline
\end{tabular}


Table 2 shows the maximum future value of the government cash flow (Criterion 1) for each Disposal Fee type. A surplus corresponds to precollecting a trust fund for future spent fuel disposal expenses. A deficit corresponds to the government funding the initial capital investment for spent fuel management. The results range from $+\$ 1433 \mathrm{M}$ to $-\$ 2405 \mathrm{M}$, with the early collections (Fees 1-2) giving surpluses while the later collections (Fees 3-5) cause deficits. It should be noted that all of the fees recover government costs by 2000 .

The economic impact (Criterion 2) of the fees on the electricity user for each disposal fee is given on Table 2. This corresponds to the amount a utility would desire to collect from electricity customers to accumulate the required disposal fee. The early collection schemes have a greater impact on the electricity price due to the higher cost of capital for utilities.

Two results are shown on Table 2 to measure the ability of the disposal fees to recover spent fuel disposal costs from the user of the electricity (Criterion 3). The first shows the range of variation of each fee when cost increases over the original estimate are assumed. The early collection schemes (Fees 1-3) have a greater variation in fee with changes in cost. This means that those fee collection schemes have a greater tendency to undercharge some group of spent fuel disposal customers and compensate by overcharging another group. The other result shown for Criterion 3 relates to the ability of a utility to recover the fee expense from the correct electricity user when spent fuel management costs, and thus fees, increase over the original estimate. The results show that the early collection schemes, where collection from the electricity user is nearer in time to the payment of the Disposal Fee, collect a higher percentage of the fee from the appropriate electricity user.

Table 2 shows the incentive for a utility to provide an additional year of at-reactor storage capability (Criterion 4) in 1987 and 1988. This incentive is represented by the amount that a utility would be willing to pay to avoid using government spent fuel storage or disposal services in 
those years. The results show that the greatest incentive is provided by the fee schemes which are based on fuel delivery to the government (Fees $3-5)$.

Fee types 2, 3 and 4 were evaluated with different spent fuel logistics assumptions to determine whether the results of the criteria evaluations would be altered. With reduced demand for both storage services and disposal services, Fees 2,3 and 4 had the same relative relationship for each of the four criteria as previously discussed. The results of this anaiysis are shown in Section 5.0. 


\section{0 CRITERIA EVALUATIONS}

The results of the analyses evaluating the candidate fees' satisfaction of the four criteria are given in the following section. The methodology used to calculate these results is discussed in Appendices $A, B$ and $C$. The data used was derived from DOE/ET-0055.

\subsection{Criterion 1: Government Outlay Should be Minimized}

The calculated fees for the five fee collection mechanisms are shown in Table 1. Storage Fees and Disposal Fees are shown separately, since not a11 customers require AFR basin storage. Fees 3-5 have different Disposal Fees for AFR storage customers and disposal customers because AFR basin customers pay their Disposal Fee in advance (at time of Storage Fee payment).

As shown in Table 1, the earlier the fee is collected, the less the fee is. This is due to decreased carrying costs which the government must recover on spent fuel management expenditures. Reduced carrying costs imply reduced government outlays, so the relative magnitudes of the fees are a measure of how well the fee collection mechanisms minimize government outlays.

A more direct comparison of government outlays for each of these schemes is shown in Figures 1-7. The future value cash flow through 1980, 1985, 1990, 1995, and 2000 is shown for each of the fee collection schemes. An early positive cash flow indicates that the fee collection scheme precollects for spent fuel management costs and creates a trust fund for future expenses. An early negative cash flow indicates that the fee collection scheme requires the government to provide initial funding for spent fuel management activities. The fee collection scheme must then recover the government investment plus carrying costs. A negative cash flow in 2000 exactly equal to the remaining value of spent fuel management facilities implies that all costs attributable to managing spent fuel received prior to 2000 have been recovered. 


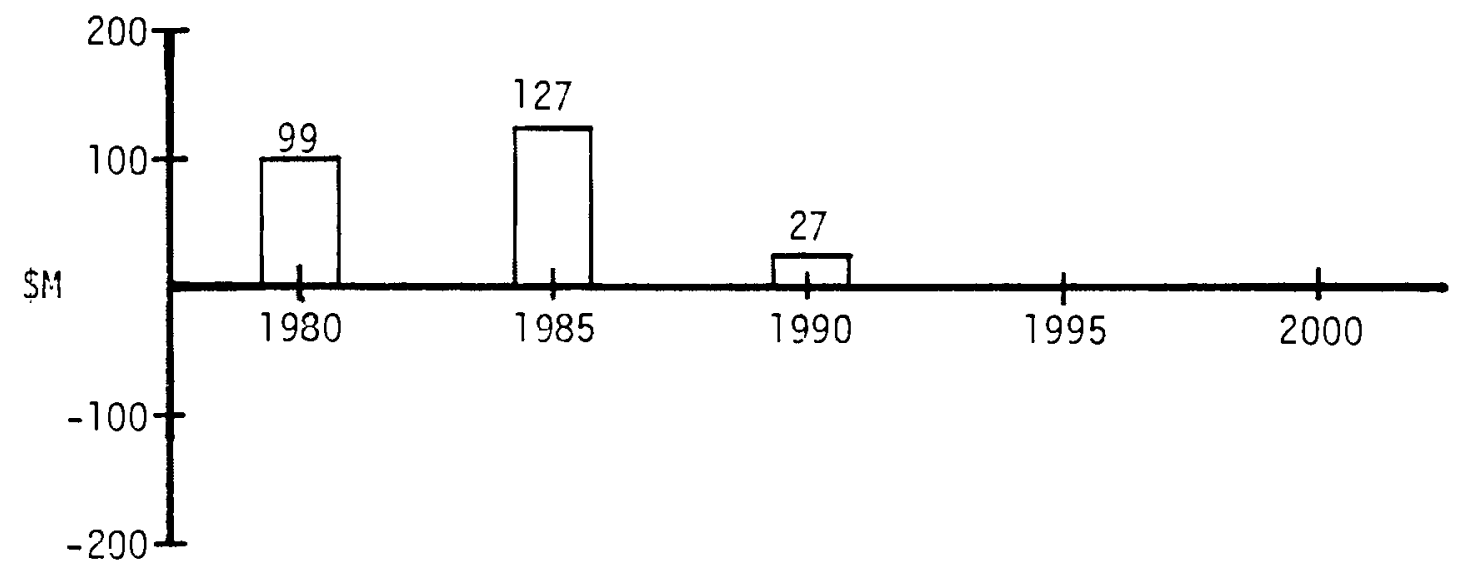

FIGURE 1. Future Value Cash Flow - Storage Fee 1-3 ( 5 Years before Fuel Delivery)






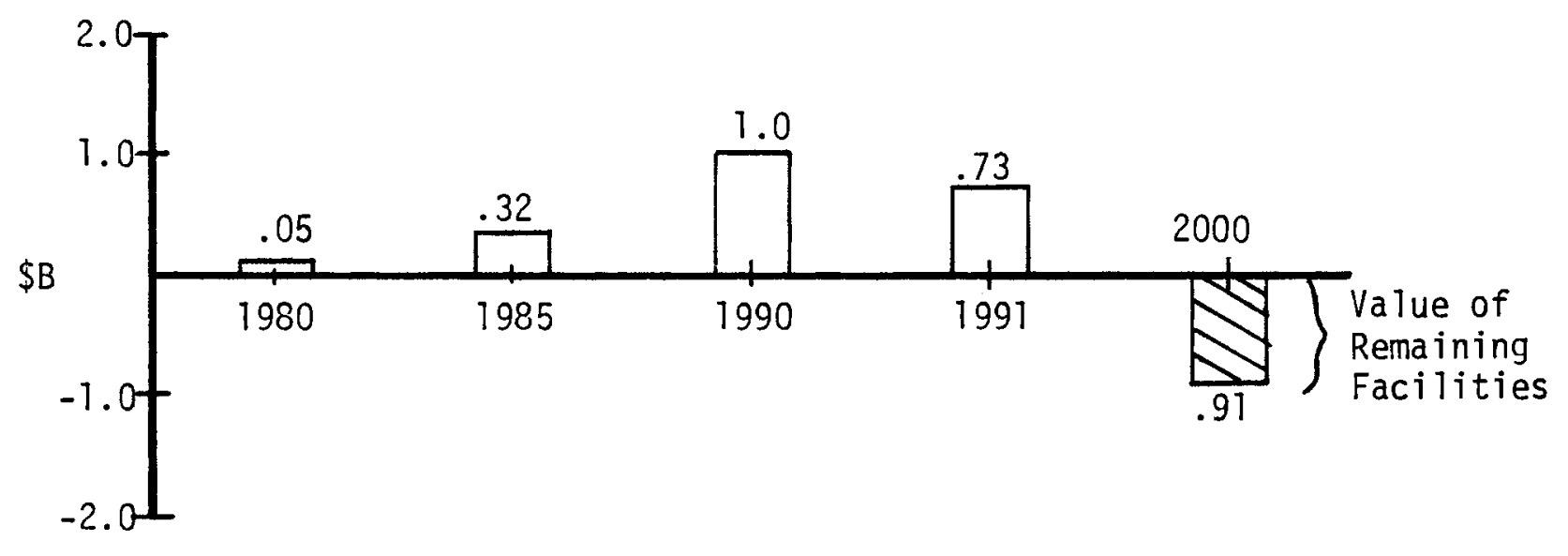

FIGURE 3. Future Value Cash Flow - Disposal Fee 1 (Power Generation)

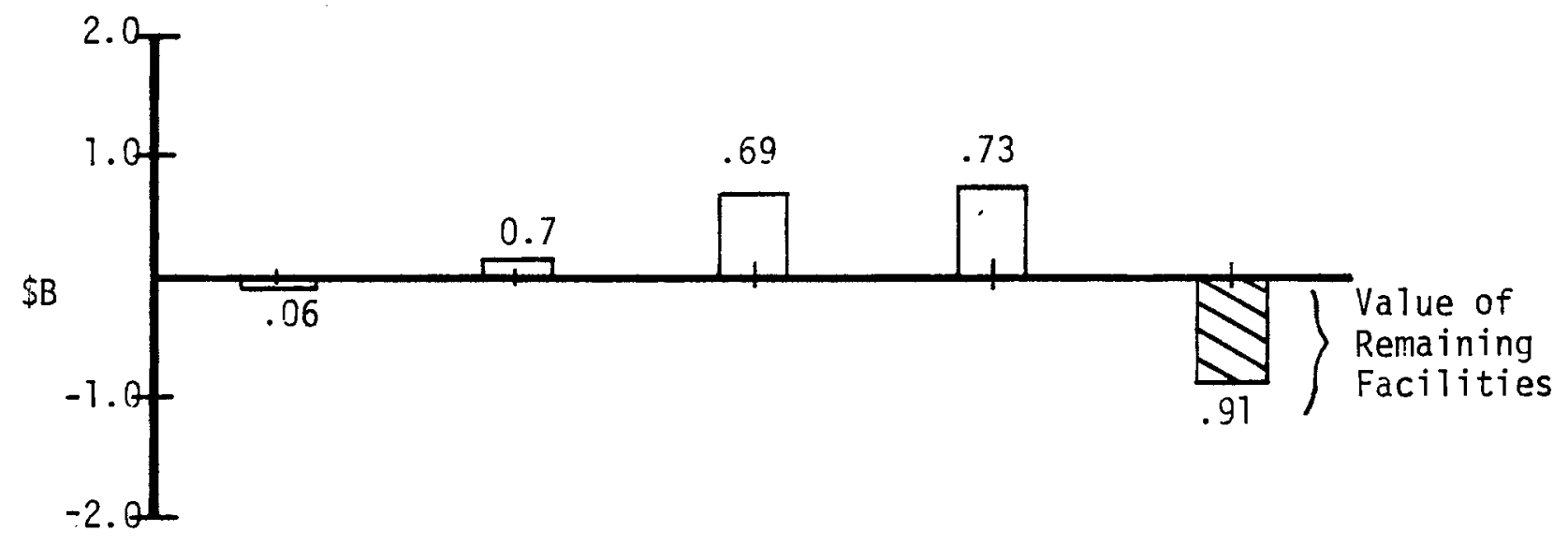

FIGURE 4. Future Value Cash Flow - Disposal Fee 2 (Fuel Discharge)

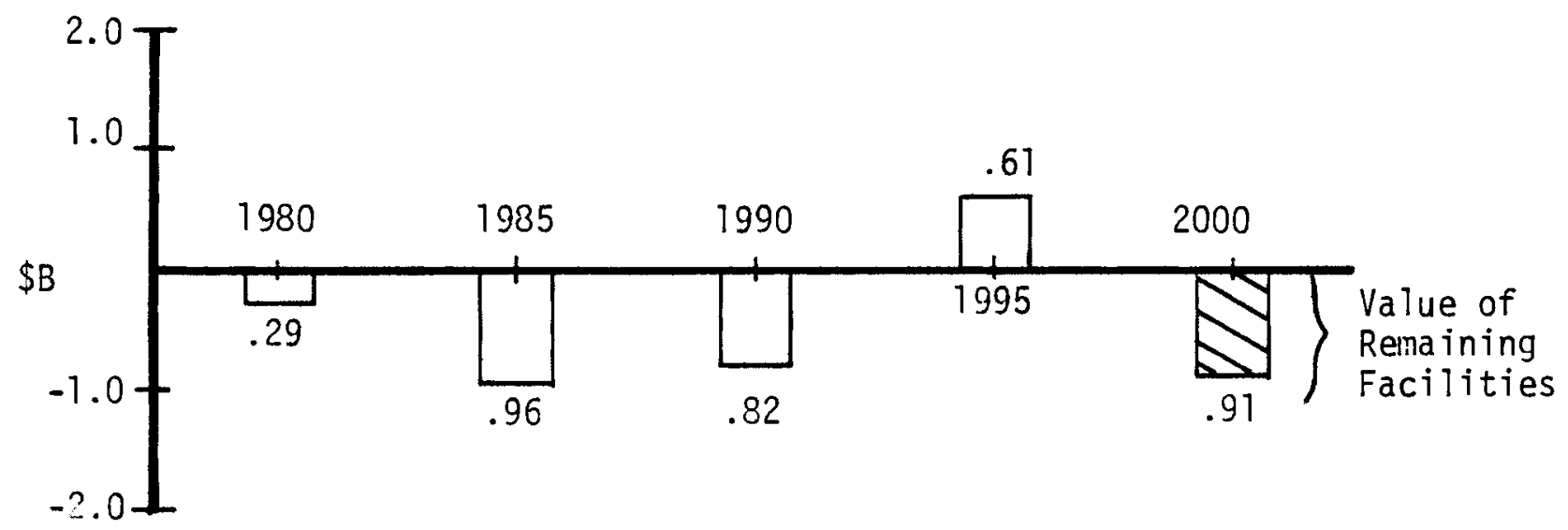

FIGURE 5. Future Value Cash Flow - Disposal Fee 3

(Five Years Before Fuel Delivery) 


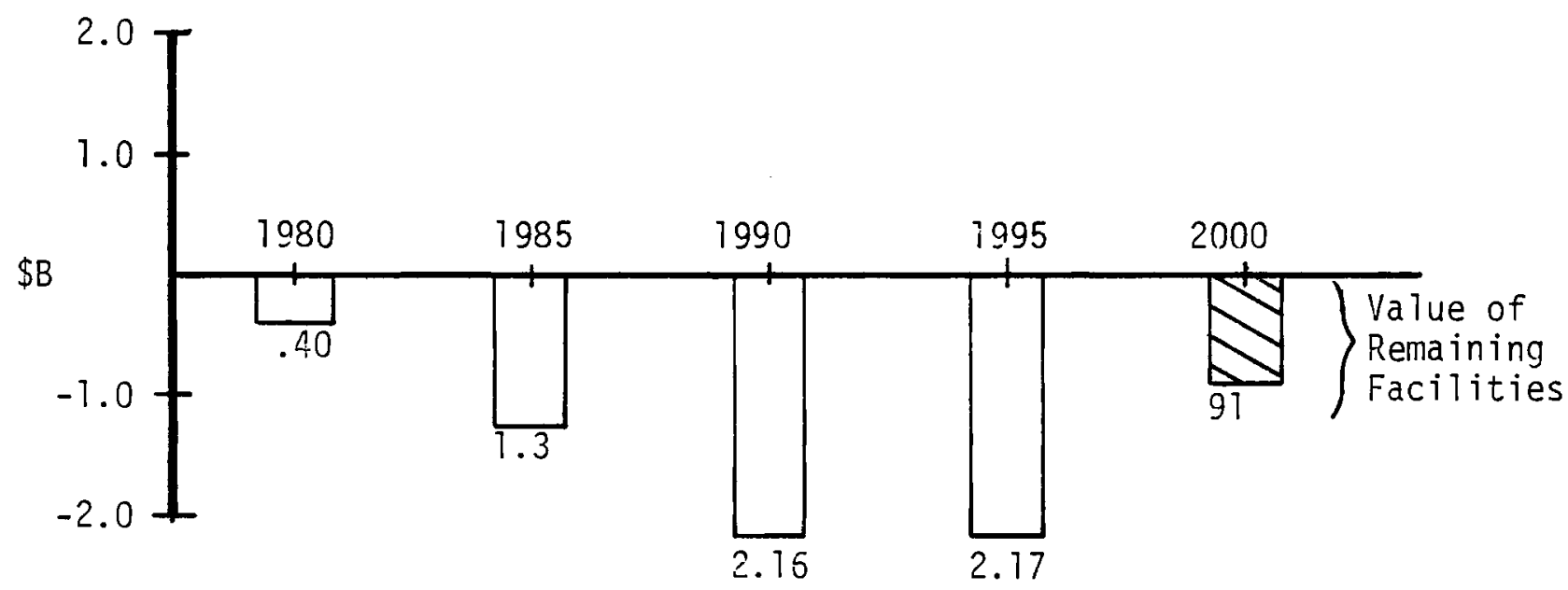

FIGURE 6. Future Value Cash Flow - Disposal Fee 4 (Fuel Delivery)

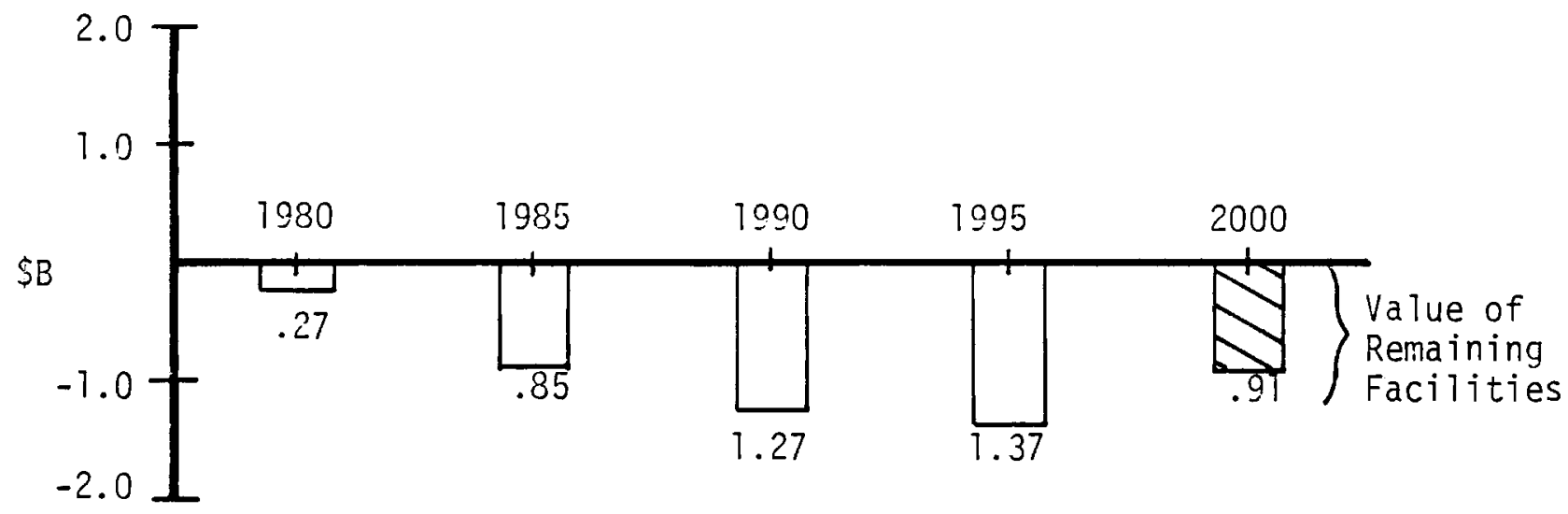

FIGURE 7. Future Value Cash Flow - Disposal Fee 5 (Power Generation and Fuel Delivery) 
Figures 1 and 2 compare the future value cash flows for the two Storage Fee schemes. Collecting the fee five years before delivery (Storage Fees 1-3) provides funding for construction of the AFR bas in (1979-1982) and a trust fund for future expenses. Collecting the fee at delivery of fuel to the AFR basin (Fees 4-5) requires an initial outlay of government funds for construction. These costs plus sufficient surplus for remaining operating and transportation expenses are recovered between 1983 and 1988.

Figures 3-7 show the future value cash flows for the Disposal Fees. Comparing the cash flows shows that the early collection schemes (Fees 1 and 2) establish government trust funds for spent fuel disposal expenses. Fee 3 results in an initial outlay of government funds, but quickly recovers that outlay and achieves a surplus for future expenses. Fee 4 requires the maximum outlay of government funds and does not fully recover government costs until 2000. Fee 5 also requires an initial government outlay which is not fully recovered until 2000, but the magnitude of the maximum future value outlay is about half that of Fee 4 . Assigning more cost components to the portion of the fee that is collected at power generation in Fee 5 could further reduce the deficit or perhaps more nearly approach the condition whereby neither large deficits nor large trust funds would be established.

\subsection{Criterion 2: The Economic Impact of the Fee Collection Mechanism on the Electricity User Should be Minimized}

Table 3 shows the costs to the electricity user for federal spent fuel disposal for each of the Disposal Fee collection schemes. These results correspond to the charge a utility would desire to pass along to the electricity user at the time of power generation to accumulate the required funds by the time the disposal fee is collected by the government. The results show that the fee collection schemes requiring early payment for spent fuel disposal have the greatest impact on the electricity user. The early payment schemes represent the highest cost to the electricity user even though the early payment schemes have lower fees (Table 1) due to decreased government carrying costs. This effect is due to the difference in the cost of capital for utilities and the federal governmient. 
TABLE 3. Cost of Spent Fuel Disposal to the Electricity User

\begin{tabular}{|c|c|c|}
\hline & Time of Fee collection & $\begin{array}{l}\text { Economic Impact of Fee } \\
\text { on Electricity Price }\end{array}$ \\
\hline Fee 1 & Power Generation & $265 \mathrm{mills} / \mathrm{kWh}$ \\
\hline Fee 2 & Fuel Discharge & $.252 \mathrm{mil1s} / \mathrm{kWh}$ \\
\hline Fee 3 & $\begin{array}{l}\text { Five Years Before Fuel } \\
\text { Delivery }\end{array}$ & $.231 \mathrm{mills} / \mathrm{kwh}$ \\
\hline Fee 4 & Fuel Delivery & $.197 \mathrm{mills} / \mathrm{kWh}$ \\
\hline Fee 5 & $\begin{array}{l}\text { Power Generation and } \\
\text { Fuel Delivery }\end{array}$ & $.216 \mathrm{mills} / \mathrm{kWh}$ \\
\hline
\end{tabular}

4.3 Criterion 3: A11 Government Costs for Spent Fuel Management Should Be Fully Recovered and Those Costs Should be Recovered from Those Using Power Generated by the Spent Fuel

If the costs associated with spent fuel management were perfectly predictable, any of the fee collection schemes would allow recovery of the cost of spent fuel management from the appropriate user of electricity. If the fee never changes, then this criterion is equally satisfiable by all five fee collection schedmes. However, if changes in the fee occur, inequities may arise. Two sorts of failure to recover costs from the appropriate customer have been examined. The first is inequitable recovery of government costs between different large groups of electricity customers, such as different utilities. The second is failure within those groups to fairly collect from individual electricity users the funds to pay the spent fuel disposal fee.

To identify and evaluate these potential inequities, changes in the reference cost data were assumed. Each year from 1980 to 1995 it was assumed that actual costs exceeded projected costs by $2 \%$. As each increase in cost was realized, projected costs were increased accordingly. Therefore, 1980 costs were assumed to exceed their original estimate by $2 \%$. Costs for 1981 were then assumed to exceed the 1980 estimate by $2 \%$, and their original 
estimate by two increases, or $4.04 \%$. Continuing this compounding process through 1995 would cause 1995 costs to exceed the original estimate by $37 \%$. The fees were computed for 1979 and recalculated for 1983, 1988, 1993, and 2001 based on costs and revenues which would have occurred by that time and projected future costs. For example, in the 1983 update, the cost increases for 1980-1983 are assumed known and projections of future costs (1984-2000) are modified accordingly. However, the increases in cost over the 1983 projection were not assumed known. These calculations model reasonably well how these fees might be updated as improved knowledge of future costs is gained. The year 2001 fee calculation occurs after all cost increases have occurred and identifies the levelized fee which would have been charged had the original cost projection matched the increased costs.

Table 4 shows the results of these analyses for the two Storage Fee options. For the case where the Storage Fee is paid five years prior to the delivery of fuel to the AFR basin, all fees have been collected before the 1983 fee update occurs. When the Storage Fee is paid at delivery to the AFR basin, all fees are collected by 1988. Since costs continue to increase over the original estimate after all fees are collected, not all costs are recovered. However, the collection at delivery option (Fees 4-5) recovers a higher percentage of costs, as indicated by the "percentage of levelized fee" shown in Table 4. The levelized fee is the fee which should have been charged to recover all costs. Approximately $91 \%$ of costs are recoverd if the fee is collected five years before delivery to the AFR basin, compared with $96 \%$ if the fee is paid at delivery to the AFR basin.

TABLE 4. Comparison of Storage Fee Collection Schemes with Cost Increases

\begin{tabular}{|c|c|c|c|c|}
\hline & \multirow[t]{2}{*}{ Time of collection } & \multicolumn{3}{|c|}{ Fee (Fraction of Levelized Fee) } \\
\hline & & $1979-1982$ & $1983-1987$ & Levelized Fee \\
\hline Fee $1-3$ & $\begin{array}{l}\text { Five Years Before } \\
\text { Delivery }\end{array}$ & $\$ 97 / \mathrm{kg}(.91)$ & -- & $\$ 107 / \mathrm{kg}$ \\
\hline Fee $4-5$ & Delivery & -- & $\$ 138 / \mathrm{kg}(.96)$ & $\$ 143 / \mathrm{kg}$ \\
\hline
\end{tabular}


Table 5 shows the same data for the candidate Disposal Fee collection schemes. The fee mechanisms which require the earliest collections show the most variation. The "percentage of levelized fee" data shows that for the hypothesized cost increase scenario the early collection schemes undercharge the early customers and overcharge later customers.

TABLE 5. Comparison of Disposal Fee Collection Schemes with Cost Increases

\begin{tabular}{|c|c|c|c|c|c|c|}
\hline \multirow{2}{*}{\multicolumn{2}{|c|}{ Time of collection }} & \multicolumn{5}{|c|}{ Fee (Fraction of Levelized Fee) } \\
\hline & & $1979-1982$ & $1983-1987$ & $1988-1992$ & $1993-2000$ & Levelized \\
\hline Fee 1 & Power Generation & $\begin{array}{c}.265 \mathrm{mill} / \mathrm{s} / \mathrm{kWh} \\
(.84)\end{array}$ & $\begin{array}{c}.294 \mathrm{mi11 \textrm {s }} / \mathrm{kWh} \\
(.93)\end{array}$ & $\begin{array}{c}.341 \mathrm{mills} / \mathrm{kWh} \\
(1.08)\end{array}$ & 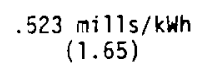 & $.317 \mathrm{mi} 11 \mathrm{~s} / \mathrm{kwh}$ \\
\hline Fee 2 & Fuel Discharge & $\$ 73 / \mathrm{kg}(.83)$ & $\$ 80 / \mathrm{kg}(.92)$ & $\$ 99 / \mathrm{kg}(1.04)$ & $5311 / \mathrm{kg}(1.27)$ & $\$ 87 / \mathrm{kg}$ \\
\hline Fee 3 & $\begin{array}{l}\text { Five Years Before } \\
\text { Delivery }\end{array}$ & $\$ 73 / \mathrm{kg}(.84) *$ & $593 / \mathrm{kg}(.90)$ & $\$ 100 / \mathrm{kg}(.97)$ & $\$ 118 / \mathrm{kg}(1.14)$ & $\$ 103 / \mathrm{kg}$ \\
\hline Fee 4 & Fuel Delivery & -- & $5105 / \mathrm{kg}(.90) *$ & $\$ 135 / \mathrm{kg}(.95)$ & $\$ 143 / \mathrm{hg}(1.01)$ & $\$ 142 / \mathrm{kg}$ \\
\hline Fee 5 & $\begin{array}{l}\text { Power Generation } \\
\text { and Fuel Delivery }\end{array}$ & $\begin{array}{c}.074 \mathrm{mills} / \mathrm{kwh} \\
(.95)\end{array}$ & $\begin{array}{c}.078 \mathrm{mi11} / \mathrm{s} / \mathrm{kWh} \\
(1.0)\end{array}$ & $\begin{array}{c}.081 \mathrm{mills} / \mathrm{kwh} \\
(1.04)\end{array}$ & 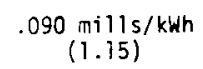 & $.078 \mathrm{mi} 11 \mathrm{~s} / \mathrm{kWh}$ \\
\hline & & $\ldots$ & $571 / \mathrm{kg}(.87) *$ & $\$ 101 / \mathrm{kg}(.94)$ & $\$ 108 / \mathrm{kg}(1.01)$ & $\$ 107 / \mathrm{kg}$ \\
\hline
\end{tabular}

*Based on reduced levelized fee for early payment with storage fee

The results on Tables 4 and 5 show that the fee collection mechanisms which require early payment are less equitable than those allowing later payment for recovering costs between large groups of electricity users. With the assumptions in this analysis, utilities requiring early services would pay less than their share while later customers would pay more. The earlier the collection of the fee, the more exaggerated the difference.

To illustrate the other type of inequity, unfair collection of the fee among electricity users within a utility, a scenario was considered in which power is being generated in 1982 with fuel which will be discharged in 1985 and shipped to the repository in 1995. Table 6 shows what the utility is expecting to pay for spent fuel disposal for each of the five collection schemes and the year the utility is expecting to make its payment. Also shown is the actual fee which will be collected in the year due if the previously discussed cost increases occur. The fee increase data is found in Table 5 . If the utility is collecting from its customers at power generation an 
appropriate amount to accumulate the spent fuel disposal fee, then that amount is proportional to the fee they are expecting to pay. If the actual fee exceeds what was expected, then too little will have been collected from the electricity user at the time of power generation. Table 6 gives the percentage of the actual fee recovered from the appropriate electricity user. The fee collection mechanisms which require early payment better satisfy this aspect of Criterion 3. For the early fee collection schemes a higher percentage of the actual fee is recovered from the user of the electricity. It should be noted that this conclusion is valid only if funds for payment of the spent fuel management fee are accumulated from the electricity customers when power is generated from the fuel.

TABLE 6. Recovery of Spent Fuel Disposal Fee from the User of Electricity

\begin{tabular}{|c|c|c|c|c|}
\hline & Time of Collection & Expected Fee & Actual Fee & $\begin{array}{l}\text { \% Recovered from } \\
\text { Electricity User }\end{array}$ \\
\hline Fee 1 & Power Generation (1982) & $.265 \mathrm{mills} / \mathrm{kWh}$ & $.265 \mathrm{mills} / \mathrm{kwh}$ & 100 \\
\hline Fee 2 & Spent Fuel Discharge (1985) & $\$ 73 / \mathrm{kg}$ & $\$ 80 / \mathrm{kg}$ & 91 \\
\hline Fee 3 & $\begin{array}{l}\text { Five Years Before } \\
\text { Delivery }(1990)\end{array}$ & $\$ 86 / \mathrm{kg}$ & $\$ 100 / \mathrm{kg}$ & 86 \\
\hline Fee 4 & Delivery (1995) & $\$ 118 / \mathrm{kg}$ & $\$ 142 / \mathrm{kg}$ & 83 \\
\hline Fee 5 & $\begin{array}{l}\text { Power Generation (1982) } \\
\text { and Fuel Delivery (1995) }\end{array}$ & $\begin{array}{c}.074 \mathrm{mill} / \mathrm{s} / \mathrm{kWh} \\
\$ 86 / \mathrm{kg}\end{array}$ & $\begin{array}{c}.074 \mathrm{mills} / \mathrm{kwh} \\
\$ 108 / \mathrm{kg}\end{array}$ & $\begin{array}{r}100 \\
80\end{array}$ \\
\hline
\end{tabular}

There is a natural tradeoff between these two aspects of satisfying criterion 3 when costs are increasing. The fee collection mechanisms which collect the fee early allow the utility to recover more of the fee from the correct electricity user. However, the fee in effect for the early fee collection schemes is less likely than later collection schemes to reflect the actual costs of spent fuel managemert.

4.4 Criterion 4: The Fee Collection Mechanism Should not Discourage Utilities from Providing their own Storage

The incentive for a utility to provide their own storage may be measured by estimsting how much they would be willing to pay to avoid using government 
services. Potential users of federal spent fuel management services fall into two distinct groups, those requiring AFR basin storage and those shipping fuel directly to the repository. Table 7 shows incentives to build one year additional at-reactor spent fuel storage capacity for these two circumstances for each fee mechanism. The incentive is measured in terms of how much a utility would be willing to spend in 1987 and 1988 to avoid delivering 25 MT (approximately one discharge) of spent fuel to the government in those years. The 1987 incentive corresponds to avoiding shipment to the AFR basin, while the 1988 incentive corresponds to delaying the first shipment to the repository one year. Table 7 shows that all payment mechanisms tend to encourage the individual utility to expand existing reactor storage facilities to avoid using Federal AFR Storage facilities. Later payment mechanisms (those tied to fuel delivery) tend to encourage at-reactor storage expansion even after the repository is available for direct disposal. Early payment mechanisms (those tied closely to power generation) encourage the utilization of repository services once they are available.

TABLE 7. Incentive to Provide Spent Fuel Storage

\begin{tabular}{|c|c|c|c|c|}
\hline & \multicolumn{2}{|c|}{ Time of Collection } & \multicolumn{2}{|c|}{ Incentive (s Millions) } \\
\hline & Storage Fee & Disposal Fee & 1987 & 1988 \\
\hline Fee 1 & $\begin{array}{l}5 \text { Years Before } \\
\text { Delivery }\end{array}$ & Power Generation & 3.9 & 0 \\
\hline Fee 2 & $\begin{array}{l}5 \text { Years Before } \\
\text { Delivery }\end{array}$ & Fuel Discharge & 3.9 & 0 \\
\hline Fee 3 & $\begin{array}{l}5 \text { Years Before } \\
\text { Delivery }\end{array}$ & $\begin{array}{l}5 \text { Years Before } \\
\text { Delivery }\end{array}$ & 5.8 & 2.4 \\
\hline Fee 4 & Fuel Celivery & Fuel Delivery & 4.9 & 2.0 \\
\hline Fee 5 & Fuel Delivery & $\begin{array}{l}\text { Power Generation } \\
\text { and Fuel Delivery }\end{array}$ & 4.3 & 1.5 \\
\hline
\end{tabular}


Fees 2, 3 and 4 were reevaluated using a modified projection of storage and disposal requirements provided by S. M. Stoller Corporation. These modified requirements and the resulting costs are shown in Appendix $D$. Table 8 gives the resulting fees for the modified projection. Table 9 gives the results of the criteria evaluations. With the altered demand for both storage and disposal services, Fees 2, 3 and 4 had the same relative relationship for each criterion as previously discussed.

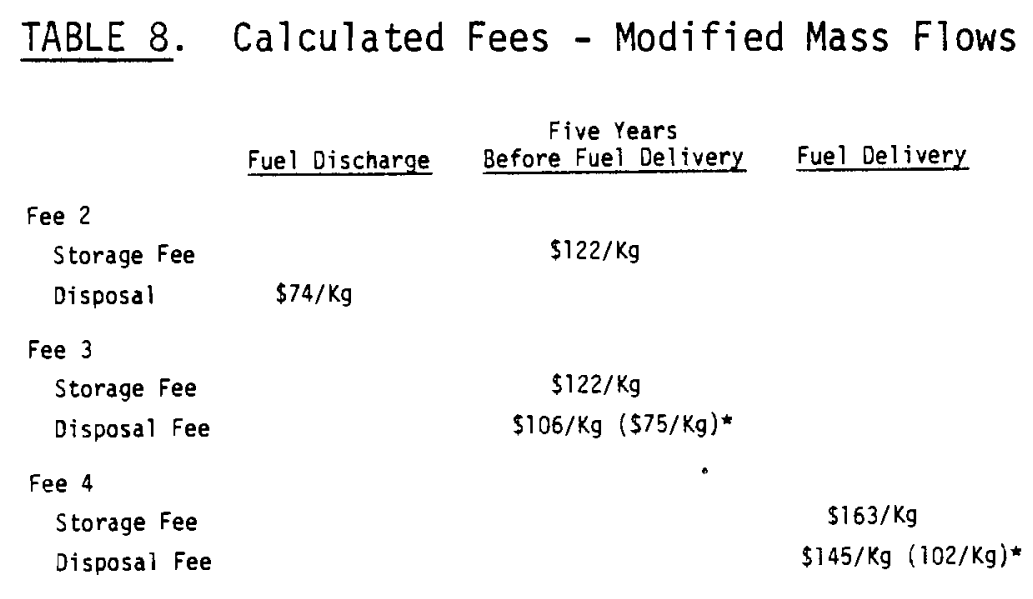

* Storage customers pay a reduced disposal fee due to early payment.

TABLE 9. Summary of Criteria Evaluations - Modified Mass Flows

\begin{tabular}{|c|c|c|c|c|c|c|}
\hline & \multirow{2}{*}{$\begin{array}{c}\text { Criterion } 1 \\
\text { Maximum } \\
\text { Future Value } \\
\text { of Government } \\
\text { Cash Flow } \\
\text { (\$Millions) }\end{array}$} & \multirow{2}{*}{$\begin{array}{c}\text { Criterion } 2 \\
\text { Economic } \\
\text { Impact on } \\
\text { Electricity Price } \\
\text { (mills/kwh) } \\
\end{array}$} & \multicolumn{2}{|c|}{ Criterion 3} & \multicolumn{2}{|c|}{ Criterion 4} \\
\hline & & & $\begin{array}{l}\text { Range of } \\
\text { Variation of } \\
\text { Fee with } \\
\text { Cost Changes } \\
\text { (percent) } \\
\end{array}$ & $\begin{array}{l}\text { Percentage of } \\
\text { Fee Recovered from } \\
\text { Electricity User } \\
\text { (percent) } \\
\end{array}$ & $\begin{array}{c}\text { Incentive to } \\
\text { Build Storage } \\
\text { in 1987 } \\
\text { (5 Milions) } \\
\end{array}$ & $\begin{array}{c}\text { Incentive to } \\
\text { Build Storage } \\
\text { in l988 } \\
\text { ( } 5 \text { Millions) } \\
\end{array}$ \\
\hline Fee 2 & 1058 & .261 & -15 to +17 & 90 & 4.9 & 0 \\
\hline Fee 3 & -762 & .225 & -11 to +12 & 86 & 6.7 & 2.9 \\
\hline Fee 4 & -2075 & .193 & -8 to +1 & 85 & 5.0 & 2.5 \\
\hline
\end{tabular}





\section{REFERENCES}

1. Prel iminary Estimate of the Charge for Spent-Fuel Storage and Disposal Services, DOE/ET-0055, Department of Energy, July 1978.

2. Report to the President by the Interagency Review Group on Nuclear Waste Management, TID-28817 (Draft), October 1978. 


\section{APPENDIX A \\ BASIC FEE METHODOLOGY AND \\ DATA FOR CRITERIA 1 AND 2 EVALUATIONS.}




\section{APPENDIX A \\ BASIC FEE METHODOLOGY AND \\ DATA FOR CRITERIA 1 AND 2 EVALUATIONS}

Each of the five fees were calculated using the basic methodology and cost data described in DOE/ET-0055. ${ }^{1}$ That methodology requires that discounted revenues equal discounted costs minus the discounted remaining value of existing facilities for the period of the fee calculation. For all of the fee calculations included in this report a $6.5 \%$ discount rate was used and the year 2000 was assumed to be the end of the fee calculation period. If the fee is assumed to be constant for the period, then the basic methodology leads to the equation

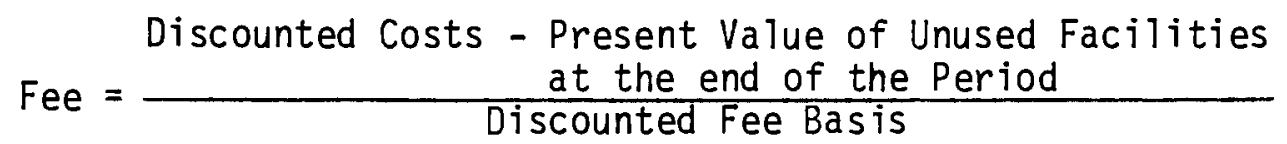

This calculation was performed for each of the five fee bases. The fee bases were derived from the fuel logistics and energy generation data shown in Table A.1 (Appendix A). The schedule for fuel delivery to government facilities and the spent fuel discharges in Table A.l are the same as was used in DOE/ET-0055. The power generation schedule was derived from the spent fuel discharge schedule using fuel burnup assumptions also found in DOE/ET-0055.

\section{STORAGE FEE CRITERION 1 EVALUATION}

The data for calculating the fee for the two storage fee options is shown on Tables A.2 and A.3. The fee bases for these calculations are the fuel delivery schedule to the AFR (A.3) and that same schedule advanced five years (A.2). Revenues and the future value cash flow are also shown in A.2 and A.3. The revenue due in 1979 for the advanced delivery shcedule basis (A.2) was assumed collected in four equal payments over four years. These payments were made equivalent to collecting the original revenue plus interest (6.5\%). This was done to provide the initial customers time to accumulate these fees. 
DISPOSAL FEE CRITERION 1 EVALUATION

The data for the Disposal Fee calculations is shown on Tables A.4 through A.10. All cost data on these tables is from DOE-ET-0055. The fee bases are the appropriate schedules from Table A.1. Annual revenues and future value cash flow to each year are also given. Revenues due in 1979 were assumed collected in four equal increments, with interest.

Tables A.4 and A.5 show the Disposal Fee calculation for Fees 1 and 2 respectively. For those fees, packaging, repository, R\&D and overhead costs are recovered over a common fee basis. The Disposal Fees for Fees 3-5 are slightly more complex. Recovery of R\&D and overhead costs for Fees 3 and 4 is based on delivery of fuel to the government. Fuel delivery data from Table A.1 is the basis for recovery of RäD and overhead costs for Fee 4 (Table A.8). That schedule advanced five years is the basis for recovery of these costs for Fee 3 (Table A.6). R\&D and overhead cost recovery for Fee 5 (Table A.10) is based on the energy generation schedule shown in Table A.1.

Recovery of packaging and repository costs for Fees $3-5$ is based on delivery of fuel to the repository. The basis for recovery of these costs for Fee 3 is the delivery schedule to the repository shown on Table A.1 advanced five years. The data for calculation of this portion of Fee 3 is given on Table A.7. Customers requiring AFR basin storage pay this portion of the fee more than five years before packaging and disposal services, as shown by the revenues in Table A.7. The fee to these early customers is discounted to account for this advanced payment. Table A.9 shows the equivalent calculation for Fees 4 and 5 based on delivery of fuel to the repository. Again, the fee for this portion of the fee is reduced for advanced payment.

The data for Fees 3-5 reported in Sections 3.0 and 4.0 for the Disposal Fees and cash flow combine these R\&D and overhead and packaging and repository components.

\section{CRITERION 2 EVALUATION}

To calculate the economic impact of the Disposal Fees on electricity users, the revenues from Table A.4-A.10 were levelized over the energy generation schedule from Table A.I using a $10 \%$ discount rate. This calculation 
determines the amount of money which a utility would need to collect from electricity customers at power generation to accumulate the funds to pay the disposal fee. 
TABLE A.1 Energy Generation and Spent Fuel Logistics

\begin{tabular}{|c|c|c|c|c|}
\hline $\begin{array}{c}\text { Energy } \\
\text { Generation } \\
\left(10^{9} \mathrm{kWh}\right) \\
\end{array}$ & $\begin{array}{l}\text { Spent Fue } \\
\text { Discharge } \\
\text { (MT) } \\
\end{array}$ & $\begin{array}{l}\text { Fuel to (from) } \\
\text { AFR Basin } \\
\text { (MT) }\end{array}$ & $\begin{array}{l}\text { Fuel to } \\
\text { Repository } \\
\text { (MT) }\end{array}$ & $\begin{array}{l}\text { Fue } 1 \text { to } \\
\text { Government } \\
\text { (MT) }\end{array}$ \\
\hline 2117.4 * & 5783 & & & \\
\hline 490.7 & 1412 & & & \\
\hline 542.1 & 1661 & & & \\
\hline 546.4 & 1944 & & & \\
\hline 568.8 & 2110 & 978 & & 978 \\
\hline 589.4 & 2261 & 429 & & 429 \\
\hline 643.4 & 2337 & 506 & & 506 \\
\hline 726.8 & 2344 & 605 & & 605 \\
\hline 838.1 & 2251 & 655 & & 655 \\
\hline 961.3 & 3213 & $(1102)$ & 1800 & 698 \\
\hline 1058.9 & 3561 & (1048) & 1800 & 752 \\
\hline 1162.2 & 3960 & (950) & 1800 & 850 \\
\hline 1243.8 & 4357 & (73) & 1800 & 1727 \\
\hline 1190.4 & 4743 & & 1800 & 1800 \\
\hline 919.5 & 5212 & & 6000 & 6000 \\
\hline 555.4 & 5662 & & 6000 & 6000 \\
\hline \multirow[t]{6}{*}{198.8} & 4189 & & 6000 & 6000 \\
\hline & & & 6000 & 6000 \\
\hline & & & 6000 & 6000 \\
\hline & & & 6000 & 6000 \\
\hline & & & 6000 & 6000 \\
\hline & & & 6000 & 6000 \\
\hline
\end{tabular}
*Fower generated in 1979 plus energy equivalent of existing spent fuel
backlog. 


\section{TABLE A.2 Storage Fee Cost Data - Fees 1-3}

(Five Years Before Fuel Delivery)

\begin{tabular}{cccc}
$\begin{array}{c}\text { Fee } \\
\text { Basis } \\
\left(10^{3} \mathrm{~kg}\right)\end{array}$ & $\begin{array}{c}\text { Cost } \\
\text { Dollars })\end{array}$ & $\begin{array}{c}\text { Revenue } \\
\left(10^{6} \text { Dollars }\right)\end{array}$ & $\begin{array}{c}\text { Cumulative Future } \\
\text { Value Cash Flow } \\
\left(10^{6} \text { Dollars }\right)\end{array}$ \\
\cline { 2 - 3 } 506 & 10 & 37 & 27 \\
605 & 15 & 86 & 99 \\
655 & 71 & 96 & 126 \\
& 105 & 101 & 123 \\
& 6 & & 124 \\
& 6 & & 126 \\
& 6 & & 127 \\
& 6 & & 130 \\
& 6 & & 132 \\
& 41 & & 96 \\
& 39 & & 61 \\
& 36 & & 27 \\
& 20 & & 0
\end{tabular}

Present Value
$(6.5 \%)$$\quad 2489 \quad 237 \quad 237$

Value of unused facilities at end of period $=0$ (undiscounted)

$=0$ (discounted $06.5 \%$ ) 
TABLE A.3 Storage Fee Cost Data - Fees 4-5 (Fuel Del ivery)

\begin{tabular}{cccc}
$\begin{array}{c}\text { Fee } \\
\text { Basis } \\
\left(10^{3} \mathrm{~kg}\right)\end{array}$ & $\begin{array}{c}\text { Cost } \\
\left(10^{6} \text { Dollars }\right)\end{array}$ & $\begin{array}{c}\text { Revenue } \\
\left(10^{6} \text { Dollars }\right)\end{array}$ & $\begin{array}{c}\text { Cumulative Future } \\
\text { Value Cash Flow } \\
\left(10^{6} \text { Dollars }\right)\end{array}$ \\
\cline { 2 - 3 } & 10 & & -11 \\
15 & & -27 \\
978 & 71 & & -104 \\
429 & 105 & & -223 \\
506 & 6 & 127 & -117 \\
605 & 6 & 56 & -76 \\
655 & 6 & 66 & -21 \\
& 6 & 79 & 49 \\
& 41 & 85 & 132 \\
& 39 & & 96 \\
& 36 & & 61 \\
& 8 & & 27 \\
& 20 & & 0
\end{tabular}

Present Value
$(6.5 \%)$$\quad 1825 \quad 237 \quad 237$

Value of unused facilities at end of period $=0$ (undiscounted)

$=0$ (discounted $0.5 \%$ ) 
TABLE A.4 Disposal Fee Cost Data - Disposa 1 Fee 1 (Power Generation)

Cumulative Future Value Cash Flow

Revenue $\left(10^{6}\right.$ Dollars) $\quad\left(10^{6}\right.$ Dollars $)$

(106 Dollars)
Fee Basis $\left(10^{9} \mathrm{kWh}\right)$

1977

1978

1979

1980

1981

1982

1983

1984

1985

1986

1987

1988

1989

1990

1991

1992

1993

1994

1995

1996

1997

1998

1999

2000

Present Value $(6.5 \%)$

Present Value

(10\%)

0
0
2117.4
490.7
542.1
546.4
568.8
589.4
643.4
726.8
838.1
961.3
1058.9
1162.2
1243.8
1190.4
919.5
555.4
198.8
0
0
0
0
0

7670

5775
40

86

120

98

98

96

120

287

250

153

123

138

142

140

143

205

511

461

332

296

276

291

281

439

Value of unused facilities at end of period $=907$ (undiscounted)

0

0

154

284

297

298

151

156

170

192

222

255

280

308

329

315

244

147

53

0

0

0

0

0

2031

1511
$-43$

$-137$

$-121$

52

247

458

511

396

324

375

492

630

800

1012

1255

1433

1225

963

725

455

191

$-108$

$-413$

$-907$

$$
=200 \text { (discounted ( } 6.5 \%)
$$


TABLE A.5 Disposal Fee Data - Fee 2

(Fuel Discharge)

\begin{tabular}{|c|c|c|c|c|}
\hline & $\begin{array}{c}\text { Fee } \\
\text { Basis } \\
\left(10^{3} \mathrm{~kg}\right) \\
\end{array}$ & $\begin{array}{c}\text { Cost } \\
\left(10^{6} \text { Dollars }\right) \\
\end{array}$ &  & $\begin{array}{c}\text { Cumulative Future } \\
\text { Value Cash Flow } \\
\left(10^{6} \text { Dollars) }\right.\end{array}$ \\
\hline 1977 & 0 & 40 & 0 & -43 \\
\hline 1978 & 0 & 86 & 0 & -137 \\
\hline 1979 & 5783 & 120 & 116 & -159 \\
\hline 1980 & 1412 & 98 & 218 & -55 \\
\hline 1981 & 1661 & 98 & 237 & 73 \\
\hline 1982 & 1944 & 96 & 257 & 233 \\
\hline 1983 & 2110 & 120 & 154 & 274 \\
\hline 1984 & 2261 & 287 & 165 & 151 \\
\hline 1985 & 2337 & 250 & 170 & 65 \\
\hline 1986 & 2344 & 153 & 171 & 77 \\
\hline 1987 & 2251 & 123 & 164 & 174 \\
\hline 1988 & 3213 & 138 & 234 & 211 \\
\hline 1989 & 3561 & 142 & 260 & 331 \\
\hline 1990 & 3960 & 140 & 289 & 493 \\
\hline 1991 & 4357 & 143 & 378 & 689 \\
\hline 1992 & 4743 & 205 & 346 & 862 \\
\hline 1993 & 5212 & 511 & 380 & 753 \\
\hline 1994 & 5662 & 461 & 413 & 724 \\
\hline 1995 & 5189 & 332 & 305 & 725 \\
\hline 1996 & 0 & 296 & 0 & 454 \\
\hline 1997 & 0 & 276 & 0 & 191 \\
\hline 1998 & 0 & 291 & 0 & -108 \\
\hline 1999 & 0 & 281 & 0 & -413 \\
\hline 2000 & 0 & 439 & 0 & -907 \\
\hline $\begin{array}{c}\text { Present value } \\
(\hat{0} .5 \%)\end{array}$ & 27875 & 2231 & 2031 & \\
\hline $\begin{array}{l}\text { Present value } \\
(10 \%)\end{array}$ & & & 1456 & \\
\hline
\end{tabular}


TABLE A. 6 R\&D and Overhead Cost Data - Disposal Fee 3

(5 Years before Fuel Delivery)

\begin{tabular}{|c|c|c|c|c|}
\hline & $\begin{array}{r}\text { Fee } \\
\text { Basis } \\
\left(10^{3} \mathrm{~kg}\right) \\
\end{array}$ & $\begin{array}{c}\text { Cost } \\
\left(10^{6} \text { Dollars }\right)\end{array}$ & $\begin{array}{c}\text { Revenue } \\
\left(10^{6} \text { Dollars }\right) \\
\end{array}$ & $\begin{array}{c}\text { Cumulative Future } \\
\text { Value Cash Flow } \\
\text { (106 Dollars) } \\
\end{array}$ \\
\hline 1977 & & 40 & & -43 \\
\hline 1978 & & 86 & & -137 \\
\hline 1979 & 1407 & 120 & 9 & -266 \\
\hline 1980 & 506 & 98 & 21 & -365 \\
\hline 1981 & 605 & 93 & 23 & -466 \\
\hline 1982 & 655 & 76 & 25 & -552 \\
\hline 1983 & 698 & 40 & 17 & -605 \\
\hline 1984 & 752 & 22 & 18 & -660 \\
\hline 1985 & 850 & 19 & 20 & -703 \\
\hline 1986 & 1727 & 17 & 41 & -726 \\
\hline 1987 & 1800 & 13 & 43 & -746 \\
\hline 1988 & 6000 & 13 & 142 & -644 \\
\hline 1989 & 6000 & 13 & 142 & -580 \\
\hline 1990 & 6000 & 13 & 142 & -490 \\
\hline 1991 & 6000 & 13 & 142 & -393 \\
\hline 1992 & 6000 & 13 & 142 & -290 \\
\hline 1993 & 6000 & 13 & 142 & -184 \\
\hline 1994 & 6000 & 13 & 142 & -65 \\
\hline 1995 & 6000 & 13 & 142 & -56 \\
\hline 1996 & & 13 & & -46 \\
\hline 1997 & & 13 & & -38 \\
\hline 1998 & & 13 & & -24 \\
\hline 1999 & & 13 & & -13 \\
\hline 2000 & & 13 & & 0 \\
\hline $\begin{array}{l}\text { Present value } \\
\quad(6.5 \%)\end{array}$ & 23929 & 566 & 566 & \\
\hline $\begin{array}{l}\text { Present value } \\
\quad(10 \%)\end{array}$ & & & 371 & \\
\hline
\end{tabular}


TABLE A.7 Packaging and Repository Cost Data - Disposal Fee 3 (5 Years Before Fuel Delivery)

\begin{tabular}{cccc}
$\begin{array}{c}\text { Fee } \\
\text { Basis }\end{array}$ & Cost & Revenue & $\begin{array}{c}\text { Cumulative Future } \\
\text { Value Cash Flow } \\
\left(10^{3} \mathrm{~kg}\right)\end{array}$ \\
\hline
\end{tabular}

1979

24

24

1980

55

80

1981

1982

5

61

140

1983

20

64

191

1984

1800

80

43

162

1985

1800

264

46

$-63$

1986

1800

231

52

$-261$

1987

1800

136

106

$-317$

1800

110

110

$-344$

1988

6000

125

367

88

1989

6000

129

367

326

1990

6000

127

367

576

1991

6000

130

367

778

1993

6000

498

367

665

1994

6000

448

367

600

1995

6000

319

367

665

283

409

283

154

278

$-132$

268

$-425$

426

$-907$

2000

1666

1466

(6.5\%)

Present value

$(10 \%)$

961

Value of unused facilities at end of period $=907$ (undiscounted)

$=200$ (discounted $0.5 \%$ ) 
TABLE A.8 R\&D and Overhead Cost Data - Disposal Fee 4 (Fuel Del ivery)



Cumulative Future $\left(10^{9} \mathrm{kWh}\right) \quad\left(10^{6}\right.$ Dollars $) \quad\left(10^{6}\right.$ Dollars $) \quad\left(10^{6}\right.$ Dollars $)$

1977

1978

1979

1980

1981

1982

1983

1984

1985

1986

1987

1988

1989

1990

1991

1992

1993

1994

1995

1996

1997

1998

1999

2000

Present value (6.5\%)

Present value $(10 \%)$

40

86

120

98

93

76

978

429

506

605

655

698

752

850

1727

1800

6000

6000

6000

6000

6000

6000

6000

6000

17504 
TABLE A.9 Packaging and Repository Cost Data - Disposal Fee 4 (Fuel Delivery)

$\begin{array}{cccc}\begin{array}{c}\text { Fee } \\ \text { Basis }\end{array} & \text { Cost } & \begin{array}{c}\text { Revenue } \\ \left(10^{3} \mathrm{~kg}\right)\end{array} & \begin{array}{c}\text { Cumulative Future } \\ \text { Value Cash Flow } \\ \left(10^{6} \text { Dollars }\right)\end{array}\end{array}$

1981

1982

1983

1984

1985

1986

1987

1988

1989

1990

1991

1992

1993

1994

1995

1996

1997

1998

1999

2000

1800
1800
1800
1800
1800
6000
6000
6000
6000
6000
6000
6000
6000

Present value 17084

$(6.5 \%)$

$\begin{array}{rrr}5 & & -5 \\ 20 & & -26 \\ 80 & 82 & -33 \\ 264 & 36 & -280 \\ 231 & 42 & -502 \\ 136 & 51 & -628 \\ 110 & 55 & -732 \\ 125 & 58 & -854 \\ 129 & 63 & -984 \\ 127 & 71 & -1110 \\ 130 & 145 & -1178 \\ 192 & 151 & -1309 \\ 498 & 502 & -1421 \\ 448 & 502 & -1488 \\ 319 & 502 & -1423 \\ 283 & 502 & -1314 \\ 263 & 502 & -1175 \\ 278 & 502 & -1047 \\ 268 & 502 & -898 \\ 426 & 502 & -907 \\ 1666 & 1466 & \end{array}$

Present value

$(10 \%)$

822

Value of unused facilities at end of period $=907$ (undiscounted)

$$
=200 \text { (discounted a 6.5\%) }
$$


TABLE A.10 R\&D and Uverhead Cost Uata - Disposal Fee 0 (Power Generation and Fue T Delivery)

\begin{tabular}{|c|c|c|c|c|}
\hline & $\begin{array}{c}\text { Fee } \\
\text { Basis } \\
\left(10^{9} \mathrm{kWh}\right) \\
\end{array}$ & $\begin{array}{c}\text { Cost } \\
\left(10^{6} \text { Dollars }\right)\end{array}$ & $\begin{array}{c}\text { Revenue } \\
\left(10^{6} \text { Dollars }\right) \\
\end{array}$ & $\begin{array}{c}\text { Cumulative Future } \\
\text { Value Cash Flow } \\
\text { (106 Dollars) } \\
\end{array}$ \\
\hline 1977 & & 40 & & -43 \\
\hline 1978 & & 86 & & -137 \\
\hline 1979 & 2117 & 120 & 43 & -232 \\
\hline 1980 & 491 & 98 & 79 & -271 \\
\hline 1981 & 542 & 93 & 83 & -306 \\
\hline 1982 & 546 & 76 & 83 & -330 \\
\hline 1983 & 569 & 40 & 42 & -247 \\
\hline 1984 & 589 & 22 & 43 & -349 \\
\hline 1985 & 643 & 19 & 47 & -344 \\
\hline 1986 & 727 & 17 & 54 & -330 \\
\hline 1987 & 838 & 13 & 62 & -304 \\
\hline 1988 & 961 & 13 & 71 & -266 \\
\hline 1989 & 1059 & 13 & 78 & -220 \\
\hline 1990 & 1162 & 13 & 86 & -162 \\
\hline 1991 & 1244 & 13 & 92 & -95 \\
\hline 1992 & 1190 & 13 & 88 & -27 \\
\hline 1993 & 920 & 13 & 68 & 23 \\
\hline 1994 & 555 & 13 & 41 & 53 \\
\hline 1995 & 1988 & 13 & 15 & 56 \\
\hline 1996 & & 13 & & 46 \\
\hline 1997 & & 13 & & 38 \\
\hline 1998 & & 13 & & 24 \\
\hline 1999 & & 13 & & 13 \\
\hline 2000 & & 13 & & 0 \\
\hline $\begin{array}{l}\text { Present value } \\
(6.5 \%)\end{array}$ & 7670 & 566 & 566 & \\
\hline $\begin{array}{l}\text { Present value } \\
(10 \%)\end{array}$ & 5775 & & 421 & \\
\hline
\end{tabular}


..

.

$\because$

?

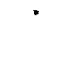


APPENDIX B

DATA FOR CRITERION 3 EVALUATIONS 


\section{APPENDIX B \\ DATA FOR CRITERION 3 EVALUATION}

The fee calculations corrected for cost increases is similar to the basic fee calculation. The fee equation is modified to account for previous revenues and to recover costs over the remaining fee basis. The discounted costs used are the historical costs up to the date of the fee correction and predicted future costs to the end of the period. The fee equation becomes



For this analysis costs were assumed to exceed projected costs by $2 \%$ for each year from 1980 to 1995. As each cost increase is realized, projected costs also increase by $2 \%$. Therefore these cost increases compound such that the 1995 cost is $37 \%$ more than the original estimate. The fee calculation was corrected to reflect these cost increases in 1983, 1988, 1993, and 2001. The 2001 calculation gives the "hindsight" levelized fee which would have been calculated if actual costs had been predicted in 1979.

STORAGE FEE EVALUATION

Table B.1 gives the 1979, 1983, and 2001 cost estimates required to calculate the storage fee. Using the 1979 estimate gives the reference result for both Storage Fee options. The 1983 cost estimate is used to correct the Storage Fee for Fees 4 and 5 . The 2001 cost estimate is used to calculate the levelized fee with all costs known.

\section{DISPOSAL FEE EVALUATION}

Table B.2 through B.4 give the 1979, 1983, 1988, 1993, and 2001 cost data required to calculate the Disposal Fees when costs are increasing as hypothesized. Using the 1979 cost data will reproduce the results for the basic fee calculation in Appendix $A$. To calculate the corrected fee components when cost increases are recognized, cost data from Tables B2-B4 must be substituted for the cost data in Tables A.4-A.10. The corrected fee is then calculated as prescribed by the above formula. 
TABLE B.1 Cost Data for Calculating Storage Fee with Cost Increases

\begin{tabular}{lrrrrr}
$\begin{array}{c}\text { Year of } \\
\text { Cost }\end{array}$ & \multicolumn{5}{c}{ Year of Updated Cost Estimate } \\
\cline { 2 - 6 } 1979 & $19 \%$ & $\underline{1983}$ & $\underline{1988}$ & $\underline{1993}$ & $\underline{2001}$ \\
1980 & 10 & 10 & 10 & 10 & 10 \\
1981 & 15 & 15 & 15 & 15 & 15 \\
1982 & 71 & 74 & 74 & 74 & 74 \\
1983 & 105 & 117 & 117 & 111 & 111 \\
1984 & 6 & 6 & 6 & 6 & 6 \\
1985 & 6 & 6 & 7 & 7 & 7 \\
1986 & 6 & 6 & 7 & 7 & 7 \\
1987 & 6 & 6 & 7 & 7 & 7 \\
1988 & 6 & 6 & 7 & 7 & 7 \\
1989 & 41 & 44 & 49 & 49 & 49 \\
1990 & 39 & 42 & 47 & 48 & 48 \\
1991 & 36 & 39 & 43 & 45 & 45 \\
1992 & 8 & 9 & 10 & 11 & 11 \\
& 20 & 22 & 24 & 26 & 26
\end{tabular}


TABLE B.2 Cost Data for Calculating Disposal Fee with Cost Increases - Fees 1 and 2

\begin{tabular}{|c|c|c|c|c|c|}
\hline \multirow{2}{*}{$\begin{array}{l}\text { Year of } \\
\text { Cost }\end{array}$} & \multicolumn{5}{|c|}{ Year of Updated Cost Estimate } \\
\hline & 1979 & 1983 & 1988 & 1993 & 2001 \\
\hline 1977 & 40 & 40 & 40 & 40 & 40 \\
\hline 1978 & 86 & 86 & 86 & 86 & 86 \\
\hline 1979 & 120 & 120 & 120 & 120 & 120 \\
\hline 1980 & 93 & 100 & 100 & 100 & 100 \\
\hline 1981 & 98 & 102 & 102 & 102 & 102 \\
\hline 1982 & 96 & 102 & 102 & 102 & 102 \\
\hline 1983 & 120 & 130 & 130 & 130 & 130 \\
\hline 1984 & 287 & 311 & 316 & 316 & 316 \\
\hline 1985 & 250 & 271 & 282 & 282 & 282 \\
\hline 1986 & 153 & 166 & 176 & 176 & 176 \\
\hline 1987 & 123 & 133 & 144 & 144 & 144 \\
\hline 1988 & 138 & 149 & 164 & 164 & 164 \\
\hline 1989 & 142 & 154 & 170 & 173 & 173 \\
\hline 1990 & 140 & 152 & 167 & 174 & 174 \\
\hline 1991 & 143 & 155 & 171 & 181 & 181 \\
\hline 1992 & 205 & 222 & 245 & 265 & 265 \\
\hline 1993 & 511 & 553 & 611 & 674 & 674 \\
\hline 1994 & 461 & 499 & 551 & 608 & 621 \\
\hline 1995 & 332 & 359 & 397 & 438 & 455 \\
\hline 1996 & 296 & 320 & 354 & 391 & 407 \\
\hline 1997 & 276 & 299 & 330 & 364 & 379 \\
\hline 1998 & 291 & 315 & 348 & 384 & 399 \\
\hline 1999 & 281 & 304 & 336 & 371 & 385 \\
\hline 2000 & 439 & 475 & 525 & 579 & 603 \\
\hline
\end{tabular}


TABLE B. 3 Cost Data for Calculating Packaging and Repository Fee with Cost Increases - Disposal Fee 3-5

\begin{tabular}{|c|c|c|c|c|c|}
\hline \multirow{2}{*}{$\begin{array}{l}\text { Year of } \\
\text { Cost }\end{array}$} & \multicolumn{5}{|c|}{ Year of Updated Cost Estimate } \\
\hline & 1979 & 1983 & 1988 & 1993 & 2001 \\
\hline 1981 & 5 & 5 & 5 & 5 & 5 \\
\hline 1982 & 20 & 21 & 21 & 21 & 21 \\
\hline 1983 & 80 & 87 & 87 & 87 & 87 \\
\hline 1984 & 264 & 286 & 292 & 292 & 292 \\
\hline 1985 & 231 & 250 & 260 & 260 & 260 \\
\hline 1986 & 136 & 147 & 157 & 157 & 157 \\
\hline 1987 & 110 & 119 & 128 & 128 & 128 \\
\hline 1988 & 125 & 135 & 149 & 149 & 149 \\
\hline 1989 & 129 & 140 & 154 & 157 & 157 \\
\hline 1990 & 127 & 137 & 152 & 158 & 158 \\
\hline 1991 & 130 & 141 & .155 & 165 & 165 \\
\hline 1992 & 192 & 208 & 229 & 248 & 248 \\
\hline 1993 & 498 & 539 & 595 & 657 & 657 \\
\hline 1994 & 448 & 485 & 535 & 591 & 603 \\
\hline 1995 & 319 & 345 & 381 & 421 & 438 \\
\hline 1996 & 283 & 306 & 338 & 373 & 389 \\
\hline 1997 & 263 & 385 & 314 & 347 & 361 \\
\hline 1998 & 278 & 301 & 332 & 367 & 381 \\
\hline 1999 & 268 & 290 & 320 & 354 & 367 \\
\hline 2000 & 426 & 461 & 509 & 562 & 585 \\
\hline
\end{tabular}


TABLE B.4 Cost Data for Calculating R\&D and Overhead Fee with Cost Increases - Disposal Fee 3-5

Year of

Cost

1977

1978

1979

1980

1981

1982

1983

1984

1985

1986

1987

1988

1989

1990

1991

1992

1993

1994

1995

1996

1997

1998

1999

2000
Year of Updated Cost Estimate

\begin{tabular}{|c|c|c|c|c|}
\hline 1979 & 1983 & 1988 & 1993 & 2000 \\
\hline 40 & 40 & 40 & 40 & 40 \\
\hline 86 & 86 & 86 & 86 & 86 \\
\hline 120 & 120 & 120 & 120 & 120 \\
\hline 98 & 100 & 100 & 100 & 100 \\
\hline 93 & 97 & 97 & 97 & 97 \\
\hline 76 & 81 & 81 & 81 & 81 \\
\hline 40 & 44 & 44 & 44 & 44 \\
\hline 22 & 24 & 25 & 25 & 25 \\
\hline 19 & 21 & 21 & 21 & 21 \\
\hline 17 & 18 & 19 & 19 & 19 \\
\hline 13 & 14 & 15 & 15 & 15 \\
\hline 13 & 14 & 16 & 16 & 16 \\
\hline 13 & 14 & 16 & 16 & 16 \\
\hline 13 & 14 & 16 & 16 & 16 \\
\hline 13 & 14 & 16 & 16 & 16 \\
\hline 13 & 14 & 16 & 16 & 16 \\
\hline 13 & 14 & 16 & 17 & 17 \\
\hline 13 & 14 & 16 & 17 & 17 \\
\hline 13 & 14 & 16 & 17 & 18 \\
\hline 13 & 14 & 16 & 17 & 18 \\
\hline 13 & 14 & 16 & 17 & 18 \\
\hline 13 & 14 & 16 & 17 & 18 \\
\hline 13 & 14 & 16 & 17 & 18 \\
\hline 13 & 14 & 16 & 17 & 18 \\
\hline
\end{tabular}


..

. 
APPENDIX C

DATA FOR CRITERION 4 EVALUATIONS 


\section{APPENDIX C \\ DATA FOR CRITERION 4 EVALUATIONS}

The incentive for a utility to provide its own storage rather than use government spent fuel storage and disposal services is calculated by determining the changes in the utility's cash flow if additional storage is provided. To illustrate this incentive, 1987 and 1988 were selected as the years additional storage might be added. Adding storage in 1987 rather than shipping fuel to the government allows the utility to avoid paying a Storage Fee. For Fees 3-5 adding such storage also defers the disposal fee. Adding a years storage in 1988 (the first year of repository operation) causes no change in cash flow if Fee 1 or Fee 2 are in effect. For Fees 3-5 disposal fees are deferred.

Appendix Table $C .1$ and $C .2$ shows the changes in utility cash flow for a utility that provides 25 MT additional (approximate average annual discharge) at-reactor storage in rather than shipping fuel to the government. The incentive is calculated by discounting the changes in cash flow to 1987 and 1988 respectively using 10\% as the approximate cost of capital to a utility. The utility would be indifferent to spending this amount to alter its cash flows as shown. 
TABLE C. 1 Changes in Cash Flow for Adding 25 MT At-Reactor Storage in 1987 (Millions of nollars)

\begin{tabular}{|c|c|c|c|c|c|}
\hline & Fee 1 & Fee 2 & Fee 3 & Fee 4 & Fee 5 \\
\hline 1982 & -2.43 & -2.43 & -4.26 & & \\
\hline \multicolumn{6}{|l|}{1983} \\
\hline \multicolumn{6}{|l|}{1984} \\
\hline \multicolumn{6}{|l|}{1985} \\
\hline \multicolumn{6}{|l|}{1986} \\
\hline 1987 & & & & -5.70 & -4.90 \\
\hline \multicolumn{6}{|l|}{1988} \\
\hline \multicolumn{6}{|l|}{1989} \\
\hline \multicolumn{6}{|l|}{1990} \\
\hline \multicolumn{6}{|l|}{1991} \\
\hline \multicolumn{6}{|l|}{1992} \\
\hline \multicolumn{6}{|l|}{1993} \\
\hline \multicolumn{6}{|l|}{1994} \\
\hline 1995 & & & +2.15 & & \\
\hline \multicolumn{6}{|l|}{1996} \\
\hline \multicolumn{6}{|l|}{1997} \\
\hline \multicolumn{6}{|l|}{1998} \\
\hline \multicolumn{6}{|l|}{1999} \\
\hline 2000 & & & & +2.95 & +2.15 \\
\hline $\begin{array}{l}\text { Discounted } \\
\text { d } 10 \% \text { to } 1987\end{array}$ & -3.90 & -3.9 & -5.84 & -4.85 & -4.28 \\
\hline
\end{tabular}


TABLE C. 2 Changes in Cash Flow for Adding 25 MT At-Reactor Storage in 1988 (Mitlions of Dollars)

Fee 1 Fee 2 Fee 3 Fee $4 \quad$ Fee 5

1982

1983

$-2.15$

1984

1985

1986

1987

1988

$-2.95$

$-2.15$

1989

1990

1991

1992

1993

1994

1995

$+2.75$

1996

1997

1998

1999

2000

Discounted

(a) $10 \%$ to 1988

$-2.36$

$+2.95$

$+2.15$

$-2.01$

$-1.46$

C. 3 
.

, 


\section{APPENDIX D}

DATA FOR REVISED STORAGE AND DISPOSAL DEMAND CALCULATIONS 


\section{APPENDIX D}

DATA FOR REVISED STORAGE AND DISPOSAL DEMAND CALCULATIONS

Table D. 1 gives a revised projection for spent fuel storage and disposal services provided by the S. M. Stoller Corporation. Demand for both storage and disposal services is reduced from that assumed in the reference calculations.

Table 0.2 gives the calculated cost data corresponding to these spent fuel logistics. The Storage Fee cost data includes the cost of building and operating a 5000 MT storage basin and the cost transporting the spent fuel from the AFR basin to the repository. The Disposal Fee cost data inciudes the construction and operating costs of the packaging facility and the repository, R\&D costs, and government overhead costs. 
TABLE D.1 Modified Spent Fuel Logistics

\begin{tabular}{|c|c|c|c|}
\hline $\begin{array}{l}\text { Spent Fuel } \\
\text { Discharge } \\
\text { (MT) } \\
\end{array}$ & $\begin{array}{c}\text { Fuel to (from) } \\
\text { AFR Basin } \\
\text { (MT) }\end{array}$ & $\begin{array}{l}\text { Fuel to } \\
\text { Reposi tory } \\
\text { (MT) } \\
\end{array}$ & $\begin{array}{l}\text { Fuel to } \\
\text { Government } \\
\text { (MT) }\end{array}$ \\
\hline \multicolumn{4}{|l|}{6134} \\
\hline \multicolumn{4}{|l|}{1405} \\
\hline \multicolumn{4}{|l|}{1557} \\
\hline \multicolumn{4}{|l|}{1744} \\
\hline 2151 & 783 & & 783 \\
\hline 2513 & 225 & & 225 \\
\hline 2761 & 258 & & 258 \\
\hline 3105 & 437 & & 437 \\
\hline 3760 & 621 & & 621 \\
\hline 3873 & & 763 & 763 \\
\hline 4227 & & 1023 & 1023 \\
\hline \multirow[t]{11}{*}{2457} & & 1290 & 1290 \\
\hline & & 1564 & 1564 \\
\hline & & 1797 & 1797 \\
\hline & & 2141 & 2141 \\
\hline & $(1000)$ & 3756 & 2756 \\
\hline & $(1000)$ & 4070 & 3070 \\
\hline & $(324)$ & 3835 & 3511 \\
\hline & & 3647 & 3647 \\
\hline & & 3801 & 3801 \\
\hline & & 3939 & 3939 \\
\hline & & 4061 & 4061 \\
\hline
\end{tabular}


TABLE D.2 Cost Data for Modified Fuel Logistics

\begin{tabular}{c} 
Stored Fee \\
Cost Date \\
$\left(10^{6}\right.$ Dollars $)$ \\
\hline
\end{tabular}

1977

1978

1979

1980

1981

1982

1983

1984

1985

1986

1987

1988

1989

1990

1991

1992

1993

1994

1995

1996

1997

1998

1999

2000
0

0

10

15

71

105

6

6

6

6

6

4

4

4

4

4

4

37

37

16

20

\section{Disposal Fee Cost Data \\ (106 Dollars)}

40

86

120

98

98

96

120

217

189

127

105

106

185

175

133

129

115

137

147

143

156

220

407

532 
$*$ 
PNL-2826

UC -70

\section{DISTRIBUTION}

No. of

Copies

\section{OFFSITE}

A. A. Churm

DOE Chicago Patent Group 9800 South Cass Avenue

Argonne, IL 60439

W. W. Ballard

Department of Energy

Washington, DC 20545

J. J. Fiore

Department of Energy

Washington, DC 20545

50

M. J. Lawrence

Department of Energy

Washington, DC 20545

A. J. Snyder

Department of Energy

Washington, DC 20545

J. P. Therault

Department of Energy

Washington, DC 20545

27 DOE Technical Information

Center
No. of

Copies

ONSITE

DOE Richland Operations Office

R. B. Goranson

H. E. Ransom

44 Pacific Northwest Laboratory

N. E. Carter

L. L. Clark

R. L. Enge] (10)

R. M. Fleischman (10)

M. A. Lewallen

R. C. Lijkala

R. W. McKee

E. T. Merril1

A. M. Platt

M. K. White (10)

Technical Information Files (5)

Publishing Coordination (2) 


\section{.}

